\title{
BOWEL INFECTION AND ACUTE APPENDICITIS
}

\author{
BY \\ M. E. E. WHITE, M. D. LORD and K. B. ROGERS
From the Children's Hospital, Birmingham
}

(RECEIVED FOR PUBLICATION JANUARY 2, 1961)

This paper seeks to correct the widely held belief that a clinical or bacteriological diagnosis of infective diarrhoea excludes the presence or development of acute appendicitis.

The work that is described was stimulated by isolated incidents that occurred between 1950-1955: these are summarized in Table 1 . In that period nine children had appendicectomies either when a bowel infection was present or before such an infection became manifest in the post-operative period: at operation four out of these nine cases were found to have acute appendicitis. A preliminary communication on the thesis of this paper was read at this hospital at a Summer meeting of the Paediatric Section of the Royal Society of Medicine in 1957 (Rogers, 1957).

Because of the findings shown in Table 1 an investigation was organized to inquire into the role of bowel infection as a factor in the aetiology of acute appendicitis: it was quite fortuitous that our planned project was started in January 1956, when a pandemic of Sonne dysentery in England was beginning.

\section{Investigations}

Main Investigation, 1956. In 1956 at the Children's Hospital Birmingham, there were 250 appendicectomies. The patients concerned represent $4.4 \%$ of a total of 5,730 patients admitted that year. Of these, 160 were suffering from acute appendicitis and all the appendices from them were examined, the distal two-thirds of each being sent for histological examination and the proximal one-third being used for bacteriological examination. When peritonitis was present, peritoneal pus or fluid was investigated. Examination and culture of the faeces were also performed. If no faeces was available a sheathed rectal swab was employed to obtain a true rectal specimen (Rogers, 1954). Twelve of the 160 patients were found to have Shigelia sonnei in their appendices and it was thought that most of these patients had dysentery due to that organism as well as acute inflammation of the appendix. Table 2 presents the main symptoms, findings at operation and bacteriological investigations of each of these 12 cases. There was, in addition, a girl (Case 13, Table 2) who developed acute appendicitis with abscess formation while she was suffering from a salmonella infection. The normal appendices removed from 20 patients, were also cultured by the same techniques and neither $S h$. sonnei nor salmonellae were isolated.

Investigations, 1957-1960. The number of appendices which are now cultured has fallen and we appear to be having a situation comparable to that seen before the Sonne dysentery pandemic of 1956 . But the bacteriological findings we have obtained have supported the evidence showing that salmonella or shigella bowel infection and acute appendicitis may be associated. The case histories of the patients in these years are summarized in Table 3.

Although the notifications of dysentery in England and Wales rose higher in 1960 than they were in 1956, the number in Birmingham did not rise. This is shown in Table 4, which presents the figures supplied by the City's Medical Officer of Health. The bacteriological findings in Birmingham are similar to those in other parts of England and Wales, where Shigella flexneri causes only about $2 \%$ of all the dysentery infection, the majority being caused by Sh. sonnei: if the Sh. flexneri infections of the mental hospitals are excluded, only $1 \%$ of the dysenteric infections in the general population are due to that organism (Carpenter, 1960). We were not surprised, therefore, when Sh. sonnei was the dysenteric organism most commonly found in the case of appendicitis.

In Glasgow dysentery infections caused by $S h$. flexneri are not uncommon. The figures given in Table 5 are extracted from the Annual Report on the work at Ruchill Infectious Diseases Hospital, Glasgow (Annual Report on the work of the Infectious Diseases Hospital in the Western Region of Scotland, 1959). They demonstrate how, in a fiveyear period, the percentage of dysenteric infections 
TABLE 1

\begin{tabular}{|c|c|c|c|c|c|}
\hline \multirow{2}{*}{ Date } & \multirow{2}{*}{$\begin{array}{c}\text { Sex and } \\
\text { Age } \\
\text { (years) }\end{array}$} & \multicolumn{2}{|c|}{ Days Before Admission } & \multirow{2}{*}{ Operative Findings } & \multirow{2}{*}{ Bacteriology } \\
\hline & & Diarrhoea & Pain & & \\
\hline $\begin{array}{c}\text { May, } \\
1951 \\
\text { July, } \\
1952 \\
\text { January, } \\
1953 \\
\text { March, } \\
1953 \\
\text { September, } \\
1953 \\
\text { February, } \\
1954 \\
\text { February, } \\
1954 \\
\text { December, } \\
1955 \\
\text { December, } \\
1955\end{array}$ & $\begin{array}{l}M / 12 \\
M / 10 \\
M / 12 \\
M / 5 \\
F / 1 \\
F / 4 \\
M / 11 \\
M / 8 \\
M / 5\end{array}$ & $\begin{array}{c}1 \\
0 \\
0 \\
0 \\
7 \\
0 \\
\text { Three attack } \\
\text { and vomitin } \\
1 \\
\text { Con- } \\
\text { stipated }\end{array}$ & $\begin{array}{c}4 \\
1 \\
4 \\
\text { Few hours } \\
7 \\
3 \\
\text { of diarrhoea } \\
\text { in two weeks } \\
0 \\
2\end{array}$ & $\begin{array}{l}\text { Normal appendix; appendicec- } \\
\text { tomy } \\
\text { Gangrenous appendix with ab- } \\
\text { scess } \\
\text { Normal appendix; appendicec- } \\
\text { tomy } \\
\text { Acute appendicitis, appendix ad- } \\
\text { herent to liver; appendicec- } \\
\text { tomy } \\
\text { Normal appendix; appendicec- } \\
\text { tomy } \\
\text { 'Congested appendix'; appendi- } \\
\text { cectomy } \\
\text { Normal appendix; appendicec- } \\
\text { tomy } \\
\text { Acute appendicitis with general } \\
\text { peritonitis; appendicectomy } \\
\text { Normal appendix; appendicec- } \\
\text { tomy } \\
\text { Appendix very inflamed; pus in } \\
\text { peritoneal cavity } \\
\text { Adherent and inflamed appendix } \\
\text { Appendix very inflamed; peri- } \\
\text { toneal toilet necessary } \\
\text { Perforated appendix; appendix } \\
\text { abscess }\end{array}$ & $\begin{array}{l}\text { Salm. enteritidis two days after appendicectomy } \\
\text { when diarrhoea developed } \\
\text { No culture of pus from abscess; Sh. sonnei from } \\
\text { faeces } \\
\text { Sh. sonnei from faeces two days after operation } \\
\text { No culture of appendix; diarrhoea developed } \\
\text { six days post operatively; wound suppuration, } \\
\text { Sh. sonnei cultured from wound pus and from } \\
\text { faeces } \\
\text { Diarrhoea occurred three days post operatively; } \\
\text { Sh. sonnei cultured from faeces } \\
\text { Diarrhoea two days post operatively; Salm. } \\
\text { typhimurium cultured from faeces } \\
\text { Diarrhoea two days post operatively; Salm. } \\
\text { typhimurium cultured from faeces } \\
\text { No culture of peritoneal pus or appendix; } \\
\text { 'routine' faeces on admission grew Sh. sonnei } \\
\text { One day post operatively Sh. sonnei cultured } \\
\text { from faeces } \\
\text { Peritoneal pus grew Sh. sonnei } \\
\text { No culture of appendix; Sh. sonnei in faeces } \\
\text { two days post operatively } \\
\text { Sh. sonnei in faeces post operatively } \\
\text { Salm. derby from peritoneal pus and post } \\
\text { operatively from faeces }\end{array}$ \\
\hline
\end{tabular}

TABLE 2

\begin{tabular}{|c|c|c|c|c|c|c|c|c|}
\hline \multirow{2}{*}{$\begin{array}{l}\text { Case } \\
\text { No. }\end{array}$} & \multirow[t]{2}{*}{ Date } & \multirow{2}{*}{$\begin{array}{c}\text { Sex } \\
\text { and } \\
\text { Age } \\
\text { (years) }\end{array}$} & \multicolumn{2}{|c|}{ Days Before Admission } & \multirow[t]{2}{*}{ Contact } & \multirow{2}{*}{$\begin{array}{c}\text { Tem- } \\
\text { perature } \\
\left({ }^{\circ} \text { F.) on }\right. \\
\text { Admission }\end{array}$} & \multirow{2}{*}{$\begin{array}{l}\text { Operative } \\
\text { Findings* }\end{array}$} & \multirow[t]{2}{*}{ Bacteriology } \\
\hline & & & Diarrhoea & Pain & & & & \\
\hline 1 & $\begin{array}{l}\text { January, } \\
1956\end{array}$ & $\mathbf{M} / 6$ & 3 & 3 & $\begin{array}{l}\text { Mother and father } \\
\text { had diarrhoea and } \\
\text { vomiting three } \\
\text { weeks before }\end{array}$ & 103 & $\begin{array}{l}\text { General } \\
\text { peritonitis }\end{array}$ & $\begin{array}{l}\text { Sh. sonnei from appendix and } \\
\text { sheath swab, not from } \\
\text { peritoneal pus }\end{array}$ \\
\hline 2 & $\underset{1956}{\text { February, }}$ & $\mathbf{M} / 6$ & 3 & $\frac{1}{2}$ & None & 100 & $\begin{array}{l}\text { Local peri- } \\
\text { tonitis }\end{array}$ & Sh. sonnei from appendix \\
\hline 3 & $\underset{1956}{\text { February, }}$ & $\mathbf{M} / 9$ & $\frac{1}{2}$ & $\frac{1}{2}$ & None & 99 & $\begin{array}{l}\text { Local peri- } \\
\text { tonitis }\end{array}$ & Sh. sonnei from appendix \\
\hline 4 & $\begin{array}{c}\text { February, } \\
1956\end{array}$ & $\mathbf{M} / 5$ & $\stackrel{14}{\text { intermittent }}$ & 1 & None & 101 & $\begin{array}{l}\text { Local peri- } \\
\text { tonitis }\end{array}$ & $\begin{array}{l}\text { Sh. sonnei from sheath swab, } \\
\text { not from appendix }\end{array}$ \\
\hline 5 & $\begin{array}{r}\text { March, } \\
1956\end{array}$ & $\mathrm{M} / 8$ & 1 & 2 & None & 103 & $\begin{array}{l}\text { General peri- } \\
\text { tonitis }\end{array}$ & $\begin{array}{l}S h \text {. sonnei from appendix } \\
\text { and sheath swab, not from }\end{array}$ \\
\hline 6 & $\underset{1956}{\text { March, }}$ & $F / 5$ & $\stackrel{5}{\text { intermittent }}$ & 5 & None & $100 \cdot 6$ & $\begin{array}{l}\text { Local peri- } \\
\text { tonitis }\end{array}$ & $\begin{array}{l}\text { Sh. sonnei from appendix } \\
\text { and sheath swab }\end{array}$ \\
\hline 7 & $\begin{array}{l}\text { April, } \\
1956\end{array}$ & $\mathbf{M} / 5$ & 2 & 2 & None & 100 & $\begin{array}{l}\text { General peri- } \\
\text { tonitis }\end{array}$ & $\begin{array}{l}\text { Sh. sonnei from appendix } \\
\text { and sheath swab, but not } \\
\text { from peritoneal pus }\end{array}$ \\
\hline 8 & $\begin{array}{l}\text { April, } \\
1956\end{array}$ & $\mathbf{M} / 8$ & 4 & 2 & 7 siblings, 2 recently & 100 & $\begin{array}{l}\text { General peri- } \\
\text { tonitis }\end{array}$ & $\begin{array}{l}S h \text {. sonnei from appendix } \\
\text { only; not from peritoneal }\end{array}$ \\
\hline 9 & $\begin{array}{l}\text { April, } \\
1956\end{array}$ & $\mathbf{M} / 12$ & & 2 & None & 100 & $\begin{array}{l}\text { Local peri- } \\
\text { tonitis }\end{array}$ & Sh. sonnei from appendix \\
\hline 10 & $\underset{1956}{\text { May, }}$ & $F / 2$ & $\begin{array}{c}4 \\
\text { at onset }\end{array}$ & 4 & $\begin{array}{c}\text { Mother had diar- } \\
\text { rhoea one week } \\
\text { before }\end{array}$ & 100 & $\begin{array}{l}\text { General peri- } \\
\text { tonitis }\end{array}$ & $\begin{array}{l}\text { Sh. sonnei from appendix } \\
\text { only, not from sheath swab }\end{array}$ \\
\hline 11 & $\underset{1956}{\text { May, }}$ & $\mathrm{M} / 8$ & 5 & 1 & None & 99 & Local peri- & Sh. sonnei from appendix \\
\hline 12 & $\begin{array}{l}\text { June, } \\
1956\end{array}$ & $\mathbf{M} / 9$ & 2 & 2 & $\begin{array}{l}\text { Sister had diarrhoea } \\
\text { and vomiting one }\end{array}$ & 103 & $\begin{array}{l}\text { General peri- } \\
\text { tonitis }\end{array}$ & $\begin{array}{l}\text { Sh. sonnei from appendix } \\
\text { and sheath swab only, not }\end{array}$ \\
\hline 13 & $\underset{1956}{\text { August, }}$ & 17 mths & $\begin{array}{l}\text { (vomiting only); } \\
\text { diarrhoea occurred } \\
\text { three days after } \\
\text { operation }\end{array}$ & 3 & None & 100 & $\begin{array}{l}\text { Retrocaecal } \\
\text { abscess }\end{array}$ & $\begin{array}{l}\text { from peritoneal pus } \\
\text { Salm. heidelberg from appen- } \\
\text { dix and sheath swab }\end{array}$ \\
\hline
\end{tabular}

Eleven of the 12 strains of Sh. sonnei were identified on the primary cultures and one was only isolated by selenite enrichment.

* All had acute appendicitis. 
TABLE 3

\begin{tabular}{|c|c|c|c|c|c|}
\hline \multirow{2}{*}{ Date } & \multirow{2}{*}{$\begin{array}{l}\text { Sex and } \\
\text { Age } \\
\text { (years) }\end{array}$} & \multicolumn{2}{|c|}{ Days Before Admission } & \multirow{2}{*}{ Operative Findings } & \multirow{2}{*}{ Bacteriology } \\
\hline & & Diarrhoea & Pains & & \\
\hline $\begin{array}{l}\text { April, } \\
\quad 1957\end{array}$ & $\mathbf{M} / 11$ & $\mathbf{0}$ & 1 & $\begin{array}{l}\text { Ileo-ileal intussusception; 'injected' ap- } \\
\text { pendix; reduction of intussusception } \\
\text { and appendicectomy }\end{array}$ & $\begin{array}{l}\text { Appendix yielded Sh. sonnei by } \\
\text { selenite enrichment only }\end{array}$ \\
\hline $\begin{array}{l}\text { April, } \\
1957\end{array}$ & $\mathbf{M} / 8$ & & 1 & $\begin{array}{l}\text { Acute appendicitis; local peritonitis; } \\
\text { appendicectomy }\end{array}$ & $\begin{array}{l}\text { Appendix yielded Sh. sonnei on } \\
\text { direct culture }\end{array}$ \\
\hline $\begin{array}{l}\text { October, } \\
1958\end{array}$ & $\mathbf{M} / 5$ & 5 hours & 5 hours & Appendicectomy; appendix showed 'acute & Both appendix and faeces grew \\
\hline $\begin{array}{l}\text { April, } \\
1959\end{array}$ & $\mathbf{F} / 6$ & 1 & 1 & $\begin{array}{l}\text { General peritonitis; appendix gangrenous } \\
\text { and perforated; partly 'walled off' by }\end{array}$ & $\begin{array}{l}\text { Mixed growth with Sh. sonnei on } \\
\text { direct culture }\end{array}$ \\
\hline July, & $\mathrm{M} / 4$ & & $1-2$ & $\begin{array}{l}\text { Gangrenous perforated retrocaecal ap- } \\
\text { pendix lying in an abscess with faecolith }\end{array}$ & $\begin{array}{l}\text { Mixed growth with a few } S h . \\
\text { sonnei on direct culture }\end{array}$ \\
\hline $\begin{array}{r}\text { August, } \\
1959\end{array}$ & $F / 7$ & $\stackrel{6}{\text { ceased }}$ at 2 & $?$ & $\begin{array}{l}\text { General peritonitis; gangrenous perfor- } \\
\text { ated appendix, partly 'walled off' by } \\
\text { omentum }\end{array}$ & $\begin{array}{l}\text { Rectal swab, peritoneal pus and } \\
\text { appendix all yielded Sh. sonnei } \\
\text { on direct culture }\end{array}$ \\
\hline $\begin{array}{r}\text { June, } \\
1960\end{array}$ & $\mathbf{M} / \frac{1}{2}$ & $\begin{array}{l}\text { For } 7 \text { days, } 14 \text { days } \\
\text { before admission }\end{array}$ & 1 & $\begin{array}{l}\text { Ileo-ileal intussusception requiring resec- } \\
\text { tion of non-viable gut; appendix nearly } \\
\text { involved in intussusception, so removed }\end{array}$ & $\begin{array}{l}\text { Sh. sonnei grown from appendix } \\
\text { whose histology showed oedema } \\
\text { and some polymorph infiltration } \\
\text { only }\end{array}$ \\
\hline
\end{tabular}

TABLE 4

NOTIFICATIONS OF DYSENTERY IN THE CITY OF BIRMINGHAM IN THE FIRST TWO QUARTERS, 1956-1960

\begin{tabular}{|c|c|c|c|c|c|c|c|c|c|c|}
\hline \multirow{3}{*}{ Year } & \multicolumn{5}{|c|}{ First Quarter } & \multicolumn{5}{|c|}{ Second Quarter } \\
\hline & \multirow{2}{*}{$\begin{array}{c}\text { Total } \\
\text { Notified }\end{array}$} & \multirow{2}{*}{$\begin{array}{c}\text { No. In- } \\
\text { vestigated }\end{array}$} & \multicolumn{3}{|c|}{ Organisms Identified } & \multirow{2}{*}{$\begin{array}{c}\text { Total } \\
\text { Notified }\end{array}$} & \multirow{2}{*}{$\begin{array}{l}\text { No. In- } \\
\text { vestigated }\end{array}$} & \multicolumn{3}{|c|}{ Organisms Identified } \\
\hline & & & Sh. sonnei & Sh. flexneri & None & & & Sh. sonnei & Sh. flexneri & None \\
\hline $\begin{array}{l}1956 \\
1957 \\
1958 \\
1959 \\
1960\end{array}$ & $\begin{array}{l}744 \\
250 \\
209 \\
194 \\
171\end{array}$ & $\begin{array}{r}431 \\
207 \\
163 \\
60 \\
46\end{array}$ & $\begin{array}{r}372 \\
87 \\
93 \\
49 \\
30\end{array}$ & $\begin{array}{r}0 \\
56 \\
0 \\
1 \\
1\end{array}$ & $\begin{array}{l}59 \\
64 \\
70 \\
10 \\
15\end{array}$ & $\begin{array}{l}305 \\
143 \\
118 \\
284 \\
181\end{array}$ & $\begin{array}{r}267 \\
104 \\
73 \\
45 \\
55\end{array}$ & $\begin{array}{r}112 \\
62 \\
48 \\
29 \\
36\end{array}$ & $\begin{array}{l}4 \\
6 \\
1 \\
1 \\
2\end{array}$ & $\begin{array}{l}51 \\
36 \\
24 \\
15 \\
17\end{array}$ \\
\hline
\end{tabular}

TABLE 5

DYSENTERY IN RUCHILL HOSPITAL, GLASGOW

\begin{tabular}{|c|c|c|c|c|c|c|c|c|c|c|c|c|}
\hline \multirow{2}{*}{\multicolumn{3}{|c|}{ Organism }} & \multicolumn{2}{|c|}{1955} & \multicolumn{2}{|c|}{1956} & \multicolumn{2}{|c|}{1957} & \multicolumn{2}{|c|}{1958} & \multicolumn{2}{|c|}{1959} \\
\hline & & & No. & $\%$ & No. & $\%$ & No. & $\%$ & No. & $\%$ & No. & $\%$ \\
\hline $\begin{array}{l}\text { Sh. sonnei } \\
\text { Sh. flexneri }\end{array}$ & $\begin{array}{l}\cdots \\
\cdots\end{array}$ & $\cdots$ & $\begin{array}{l}408 \\
323\end{array}$ & $\begin{array}{l}56 \\
44\end{array}$ & $\begin{array}{r}485 \\
78\end{array}$ & $\begin{array}{l}86 \\
14\end{array}$ & $\begin{array}{r}326 \\
48\end{array}$ & $\begin{array}{l}87 \\
13\end{array}$ & $\begin{array}{l}328 \\
107\end{array}$ & $\begin{array}{l}75 \\
25\end{array}$ & $\begin{array}{l}278 \\
206\end{array}$ & $\begin{array}{l}57 \\
43\end{array}$ \\
\hline Total & . & $\cdots$ & 731 & & 563 & & 374 & & 435 & & 484 & \\
\hline
\end{tabular}

due to Sh. flexneri was very much higher than is usual in England and Wales. In February 1959, a girl of 15, who had had diarrhoea for one day was admitted to the Royal Infirmary, Glasgow; Sh. flexneri was isolated from her faeces, but her abdominal pain increased and appendicectomy was performed. At operation an inflamed appendix was found, without any pus formation or peritonitis (Patrick, 1959).

\section{Diagnosis}

The differential diagnosis of acute appendicitis in children has been discussed at length by Williams (1947) and Brown (1956). Both these authors draw attention to the fact that the 'difficult case' is the patient who does not have abdominal pain as the presenting and predominating symptom; they point out that diarrhoea, contrary to time-honoured orthodox surgical teaching, is a very common alternative manner of presentation. This diarrhoea, associated with vomiting, may precede or concur with the abdominal pain.

Campbell and McPhail (1958) noted that $16 \%$ of 450 adult cases with acute appendicitis had a history of diarrhoea, whilst Brown (1956) found this symptom in $12 \%$ of 1,148 children suffering from appendicitis. Zachary Cope (1957) draws attention to the fact that appendicitis in children may be heralded by the passage of loose stools. While it is recognized that diarrhoea may occur late in the disease, indicating the presence of a pelvic abscess, little attention has been paid to the significance of 
diarrhoea as an early symptom. In the 160 cases studied in 1956, diarrhoea was an early symptom in $28(17 \cdot 5 \%)$. Amongst these 28 cases, were the 12 who were subsequently found to be suffering from Sonne dysentery. In four of these 12 children with shigella infections, diarrhoea preceded the abdominal pain: in seven, abdominal pain occurred at the same time as the diarrhoea and in one the diarrhoea started after the pain. The child with salmonellosis was constipated until three days after operation, when diarrhoea developed.

Vomiting occurred as an early symptom in 118 of the 160 patients studied $(73 \cdot 3 \%)$ and in 10 of the 12 patients with Sonne dysentery.

The physical signs we have used in the diagnosis of acute appendicitis in our children have been essentially those evaluated and found reliable in adults by Campbell and McPhail (1958); moreover, we have not found that they differ when there is concomitant dysenteric infection.

All our patients were pyrexial, but their fever showed no unusual features. Those patients with localized infection had temperatures of $100^{\circ} \mathrm{F}$. or below: those patients with general peritonitis had temperatures of $101^{\circ}$ to $103^{\circ} \mathrm{F}$.

When allowance is made for the natural apprehension of the very young, and if gentleness is used and care taken not to alarm a frightened child, the signs of tenderness, guarding and release pain, in the right lower quadrant of the abdomen, are as valid in children as in adults, and the same applies to rectal tenderness.

In some patients the diagnosis of appendicitis was delayed because of the clinical picture of infective diarrhoea, and it is noteworthy that six of the 12 cases with Sonne dysentery had general peritonitis.

\section{Treatment}

In the 160 cases described in this study, appendicectomy was performed with or without drainage. Patients with general peritonitis received intravenous therapy and gastrointestinal suction. The dysenteric infection was treated in 11 cases with oral streptomycin $0.5 \mathrm{~g}$. b.d. for seven days. One child received oral phthalyl sulphathiazole 1 g. q.d.s. for seven days. The children were considered free of infection after specimens of faeces obtained on three consecutive days had been examined and found to be free from the presence of Sh. sonnei (Rogers, 1954).

\section{Bacteriological Techniques}

The fragment of appendix sent for a cultural examination was placed in a sterile 1-oz. screw- topped bottle: in the laboratory this was cultured as if it was pus (Rogers, Zinnemann and Foster, 1960), and also as if it was faeces (Rogers, 1954). Strains of Sh. sonnei and salmonellae were first identified by slide agglutination and then this identity was confirmed by tube agglutination using a centrifuge, a method which provides a quick confirmation of the slide agglutination result (Rogers, Dowse and Hall, 1959). Other routine confirmatory tests were made and the in vitro antibiotic sensitivity reactions of each strain were examined, but no attempt was made to phage or colicine type them during 1956 . Some of the strains isolated in 1959-60 have been colicine typed, but no single type was found to be associated with appendicitis.

\section{Discussion}

Several authors described how either Salm. typhi or Salm. paratyphi B were isolated from the appendix or the peritoneal pus removed from patients with acute appendicitis (Mackenzie, 1903; Wilde, 1930; Hawkes, 1939; Storey, 1954), Rubenstein and Johnson (1945) reviewed the literature on the subject and reported that a boy of 14 , who had been under their care, developed appendicitis whilst suffering from salmonellosis due to Salm. newport, and that a 42-year-old man had a gangrenous appendix removed when he had salmonellosis due to Salm. oranienberg. There have been fewer reports in which the association of shigellosis and acute appendicitis has been proved. Graham (1944) reported that amongst 550 American troops, with dysentery due to Sh. newcastle, four also suffered from acute appendicitis, the appendices showing catarrhal changes.

Rose (1945) described how a man of 30, who had clinical dysentery due to Sh. flexneri, developed appendicitis two weeks later: no dysentery organisms were isolated from the foul pus found at operation: another man of 29 had mild clinical dysentery and acute appendicitis, but at no time were shigellae isolated from his faeces: Sh. shigae were isolated from the pus found at operation. Cowan (1958) reported 10 cases of acute appendicitis occurring amongst 345 patients with mild clinical dysentery: no bacteriological investigations were made.

The changes in the pattern of Sonne dysentery, which have occurred since 1947, have been discussed by Taylor (1957): it is possible that this change might be due to new strains brought to England in the post-war years by returning troops and transient foreign visitors (Lancet, 1956), but this increasing frequency of Sonne dysentery makes it important for the association of dysentery and appendicitis to be appreciated in Great Britain. 
Rendle Short (1935) wrote: 'Pain associated with diarrhoea ... is unlikely to have surgical significance'. Burrill Crohn (1945) stated: 'Diarrhoea and appendicitis rarely concur and it is a safe rule that fever, tenderness, and even rebound tenderness, in the presence of diarrhoea are almost invariably due to an acute gastro-enteritis or ileitis', but he admitted that if there were conditions of epidemic or endemic dysentery, a diagnosis of acute appendicitis could be seriously considered.

Several writers (Kross and Schiff, 1940; Keeling, 1942; Rose, 1945; Keyes and Cook, 1946), have emphasized how difficult it is to differentiate between appendicitis and dysentery. Rubenstein and Johnson (1945) showed how the white cell count was of no value in making this differential diagnosis; we agree that there is often a polymorphonuclear leucocytosis in a patient who is dehydrated, which can easily occur when a child has dysentery.

Many authors recorded that faecoliths were present or there was evidence of previous damage to the appendix in the patients who had this dual pathology. Perry and Tidy (1918) suggested that the intestinal disturbance of dysentery was liable to cause irritation of a previously diseased appendix, and Rose (1945) noted the presence of a faecolith in both his patients who had acute appendicitis due to shigellosis, as did Widal (1913) in the appendix abscess of his patient who had paratyphoid fever. Macroscopic and microscopic examinations of the appendix of each of our cases showed acute suppurative inflammation, progressing in some cases to gangrene and perforation, and no evidence was found which did not support the view of Wangensteen and Bowers (1937) and Bowers (1939) that obstruction was the exciting factor in the development of acute appendicitis.

It was our opinion that mucosal oedema was the precipitating factor in the development of the acute appendicitis, as a partial obstruction then became complete. Enterogenous infection of the appendix by bacteria, which may be recognized pathogens, may account for a larger number of cases of acute appendicitis than we had hitherto believed, especially those in which diarrhoea is an early symptom. Such a theory might revive the 50-year-old beliefs of Aschoff that the exciting cause of acute appendicitis was mucosal infection (Aschoff, 1932).

The awareness of the association of infective diarrhoea and acute appendicitis, which we have in fact shown to exist, is essential if a correct diagnosis is not to be delayed. The risk of hospital cross-infections will be reduced if patients with acute appendicitis, who might also have dysentery, are admitted to isolation wards or barrier nursed, until the bacteriological investigations are completed. In this hospital any non-lactose fermenting enterobacteriaceae is examined to ensure that salmonellae and shigellae are always identified: we are not the first to consider this logical, for in 1945 Rubenstein and Johnson advocated that appendices should be cultured on selective media to allow salmonellae or shigellae to be isolated, and the interesting report of Hormaeche, Surraco, Peluffo and Aleppo (1943) make it obvious that this is also the rule in their laboratory.

\section{Summary}

The evidence collected in a children's hospital over a period of 10 years has shown that acute appendicitis may be precipitated by a bowel infection. Symptoms and signs suggestive of acute appendicitis demand operation, even though a bowel infection may be known to be present. It is considered that an appreciation of this possible dual pathology will help to prevent hospital crossinfection due to salmonellae and shigellae. Previously published literature on the subject has been reviewed and discussed.

We would like to express our gratitude to the surgeons of the Children's Hospital, Birmingham, for allowing us access to the patients under their care; to the resident clinical pathologists who have helped with this work; to Drs. Matthew Burn and E. L. Millar and Professor Tom Anderson for epidemiological information, and Drs. Henry Baar and Hugh Cameron for permission to use their histological findings.

\section{REFERENCES}

Annual Report on the work of the Infectious Diseases Hospital in the Western Region of Scotland, 1959.

Aschoff, L. (1932). Appendicitis: its Aetiology and Pathology. Translated by G. C. Pether. Constable, London. (First

published, 1912.)
Bowers, W. F. (1939). 'Appendicitis' with especial reference to pathogenesis, bacteriology and healing. Arch. Surg. (Chicago), $39,362$.

Brown, J. J. Mason (1956). Acute appendicitis in infancy and childhood. J. roy. Coll. Surg. Edinb., 1, 268.

Campbell, J. A. and McPhail, D. C. (1958). Acute appendicitis. Brit. med. J., 1,852 .

Carpenter, K. P. (1960). Personal communication.

Cope, Z. (1957). The Early Diagnosis of the Acute Abdomen. Oxford University Press, London.

Cowan, D. J. (1958). Appendicitis and acute terminal ileitis during an outbreak of gastro-enteritis among British troops in Port Said. Brit. med. J., 1, 438 .

Crohn, B. B. (1945). Acute appendicitis and diarrhea. Gastroenterology, 4, 511 .

Graham, W. H. (1944). Diagnosis of appendicitis with gastroenteritis. Milit. Surg., 95, 296.

Hawkes, S. Z. (1939). Paratyphoid fever complicated by ruptured appendicitis. Ann. Surg., 110, 466.

Hormaeche, E., Surraco, N. L., Peluffo, C. A. and Aleppo, P. L. (1943). Causes of infantile summer diarrhea. Amer. J. Dis. Child., 66, 539.
(1943).

Keeling, J. (1942). Salmonella septicaemia. A report of seven cases. N.Z. med. J., 41, 254.

Keyes, E. L. and Cook, M. M. (1946). Diagnosis of acute appendicitis in the presence of diarrhea. Arch. Surg. (Chicago), 52, 429. 
Kross, I. and Schiff, F. (1940). Pseudosurgical syndromes produced by salmonella organisms. Amer. J. dig. Dis., 7, 176.

Lancet (1956). Leading article. 'More dysentery.' 2, 878.

Mackenzie, H. W. G. (1903). Perforation in typhoid fever. Lancet, 2,863

Patrick, W. (1959). Personal communication.

Perry, H. M. and Tidy, H. L. (1918). A report on the investigation of an epidemic caused by bacillus aertryche. Spec. Rep. Ser. med. Res. Comm., No. 24

Rendle Short, A. (1935). Abdominal pain in children. Brit. med.J. $1,1157$.

Rogers, K. B. (1954). Clinical pathology in general practice. Examination of faeces for infection and infestation. Ibid. $1,147$.

(1957). The association of acute appendicitis with infective diarrhoea. Proc. roy, Soc. Med., 50, 1025.

, Dowse, J. E. and Hall, J. T. (1959). Techniques used in the routine examination of specimens for the specific serological types of Escherichia coli. J. clin. Path., 12, 191.
Zinnemann, K. and Foster, W. P. (1960). The isolation and identification of Haemophilus spp. from unusual lesions in children. Ibid., 13, 519 .

Rose, T. F. (1945). The clinical differentiation of appendicitis and the dysenteries. Med. J. Aust., $2,72$.

Rubenstein, A. D. and Johnson, B. B. (1945). Salmonella appendicitis. Amer. J. med. Sci., $210,517$.

Storey, G. W. (1954). The pathology of salmonella food poisoning. M.D. Thesis, Liverpool University.

Taylor, I. (1957). The changing epidemiology of Sonne dysentery. Proc. roy. Soc. Med., 50, 31

Wangensteen, O. H. and Bowers, W. F. (1937). Significance of the obstructive factor in the genesis of acute appendicitis: an experimental study. Arch. Surg. (Chicago), 34, 496.

Widal, F. (1913). Rapport sur un travail de M. Walther concernant un cas d'appendicite paratyphique. Bull. Acad. Méd. (Paris), 69,283 .

Wilde, J. F. (1930). Acute appendicitis complicated with paratyphoid fever. Brit. med. J., 1, 16.

Williams, H. (1947). Appendicitis in the young child. Ibid., 2, 730. 